\title{
15 Regression to the increasingly mean? \\ Private health insurance in the United States of America
}

\author{
LAWRENCE D. BROWN AND SHERRY A. GLIED
}

Life can be a tale of woe so people contrive arrangements that insulate them from the consequences of some familiar feared mishaps. Insurance - a small present payment in promise of larger compensation in the event of future losses - is one such arrangement. Insurance contracts recompense policy-holders for, for instance, loss of or damage to their home in a fire or their car in an accident, or the death of a benefactor who took out life insurance. People may also buy insurance that will cover some (maybe most) of their medical costs if they or members of their family fall ill and need care.

In health policy parlance the options for insurance are often dichotomized between private and public but both terms are partly misnomers. In theory, an individual called an insurer might bet (gamble) on the continued good health of another individual called the insured, but in practice those in the insurance game insure pools of people and rely on the law of large numbers to turn the profits that make it worth their while playing that game in the first place. So-called private health insurance, then, has an inescapably social character. Public health insurance, meanwhile, is an entitlement to care (or anyway, to have most medical bills covered) conferred by the state on its citizens by law. The contract in question is social/political/legal, a right of citizenship, not the product of decisions made by consumers.

Private health insurance is socialized risk pooling and risk sharing managed by non-public entities, which might be so-called private organizations with a public charter (European sickness funds, for example) or for-profit or voluntary insurance firms operating under public rules of greater or lesser scope and specificity. In most Western nations private insurance has a complementary or supplementary role: it covers co-payments (as in France), for instance, or services that the basic public plan does not (as in Canada) or that are delivered in ways that 
are distinct from those of the public plan (access to the private sector in the United Kingdom). In some societies private insurers sell coverage within a set of government rules that regulate what they offer and how (for instance, Switzerland and - since 2006 - the Netherlands). And in one country (the United States of America) private carriers supply the preponderance of health coverage within government constraints that leave purchasers and insurers considerable discretion as to who gets covered for what, on what terms and at what price. However, since the passing of the Affordable Care Act in 2010, comprehensive health reforms have been implemented to protect consumers from the exclusionary practices of the insurance industry (US Department of Health and Human Services, 2015).

Health insurance of whatever type rests on two axioms. First, everyone is vulnerable to illness, perishable and mortal (a sameness principle, so to speak). Second, illness strikes different people differently (the difference principle). Most nations emphasize the sameness principle and pay little policy attention to the differences. The United States does the reverse. Most nations ponder what particularistic accent marks to paint on their broad universalist canvas. The United States wonders how its particular parts can be made to sum to something closer to a universalist whole. The United States is, then, as everyone knows, an international outlier, an exceptional case in its reliance on weakly regulated private health insurance as its basic source of basic coverage. This chapter reviews how and why this happened, why the pattern endures, and what it means for such evaluative criteria as adequacy and equity of coverage. It also looks at how the arrival of the Patient Protection and Affordable Care Act (ACA), passed in March 2010 but now under threat of repeal, has changed and may continue to change the privatist picture.

\section{Emergence of private health insurance}

Before the early 20th century, the demand for health insurance was weak because health care was rarely efficacious or costly. The main concern - impoverishment when illness cost workers their wages or jobs - was addressed mainly by fraternal associations and unions (Starr, 1982; Hacker, 2002: p.53), which also occasionally contracted with medical providers to care for their members for prepaid sums. As the quality and cost of medical care began rising, European and American 
paths diverged. Germany launched public health coverage for workers in 1883 and Britain did likewise in 1911, for example. In the United States Theodore Roosevelt, though a surpassingly rugged individualist, called for something similar, as did the American Association for Labor Legislation, but physicians and business groups protested vigorously, and then the First World War and the Russian Revolution rendered anything German or socialized unfit for mention in polite society. A handful of large commercial insurers began to apply the practices of the life insurance trade to health coverage (Starr, 1982; Hacker, 2002; Klein, 2003), but such products achieved very low penetration. And so matters stood when the Depression struck in 1929 and raised a number of questions about health coverage.

Economic collapse damaged both consumers (who were less inclined to seek medical care) and providers (whose bills were less inclined to get paid). Leftist reformers within and around the New Deal programmes of President Franklin D. Roosevelt detected a window of opportunity and pushed Roosevelt to include national health insurance (NHI) alongside other welfare state staples such as social security, public assistance and unemployment compensation, which he was in the process of pushing through Congress. Various political streams (Kingdon, 2003) converged, however, to slam the window shut: strident antipathy from physicians roused to active opposition by the broad reform agenda of the Committee on the Cost of Medical Care (Fox, 1986: pp.50-1); whispers in Roosevelt's ear by trusted physicians about the alleged miseries of Germany's health system (Swenson, 2008); and the unwillingness of the president and his aides to spend large amounts of political capital in a battle with doubtful prospects when so many other conflicts beset the New Deal (Hacker, 2002). Roosevelt would revisit the issue rhetorically by including universal health coverage in the Economic Bill of Rights that he sketched in 1944, but by then the nation was at war and the providers, perhaps sensing that the best defence against NHI was a good offence, had concocted a seemingly feasible alternative - Blue Cross and Blue Shield.

\section{The third sector}

From a historical and social point of view it is misleading to portray so-called private health insurance as roaring out of the Depression to conquer the field of coverage. This view discounts the inestimable 
importance, then and still, of the third sector, that is, health insurance institutions designed to mirror the character of voluntary hospitals and physicians (whose presentation of self to themselves and the public highlighted their commitment to professionalism, not profit). Voluntary hospitals held a position of special virtue in between the politics of the public sector and the profit seeking of the private sector. Graced with a community-service mission and unpaid boards of trustees drawn from community elites, they stood alone, aloof and above the tainted preserves of politics and profit. (In this they also resembled the philanthropic foundations that then supplied much of their capital.) Blue Cross was essentially a financing arm for the voluntary hospitals, and built in their normative image. The comparative oddity of the origins of private health coverage in the United States - the insurance system was invented by and for providers themselves - should not obscure the nuanced nature of a private system that rested on three pillars - voluntarism (the third sector), cooperation (insurance would be marketed to local purchasers who could accept, reject or bargain over it as they pleased) and community (these private insurers elevated service and benefits for the community above the profits they formally did not accrue). [For more on Blue Cross see Law (1974), Anderson (1975), Brown (1991) and Chapin (2015).]

As so often happens in American life, these assertions of special virtue were accompanied by claims to special advantage. In recognition of the benefits the so-called Blues conferred on their communities and their charitable contributions, state after state and then the federal government exempted them from taxes, a competitive edge that tilted the playing field against their commercial competitors. Adorned with a moral halo, official sponsorship of the American Hospital Association, and special public status - which helped the American Hospital Association to achieve "a virtual monopoly over health pricing in most communities" (Quadagno, 2005: pp.23-4) - Blue Cross and Blue Shield (which formed its first plan with that name and the shield logo in 1939) rapidly gained subscribers.

By showing that this distinctively American gambit in voluntary, cooperative and community-based coverage could work, the growth of Blue Cross illuminated, and in some measure tamed, the terrain for commercial insurers. Voluntary health insurance thus begat private counterparts - or at any rate, encouraged these latter carriers to be fruitful and multiply. This they did partly by checkmating the Blues' 
tampering with the playing field via tax advantages with an innovation of their own, imported from the life insurance field - experience rating, which helped the commercials to gain market share by offering purchasers rates tailored to the particular demographics and use patterns of their workforces and union memberships. The Blues' community rating (one family rate across the community regardless of age, health status and the like) had been a circumscribed voluntarist exercise in solidarity. Experience rating signalled the arrival of hard-nosed private "actuarial fairness" (Stone, 1993), the feature that most powerfully gave the private US health insurance industry its industrial strength - and societal weakness.

During the 1930s the contest among the Blues, their small but gaining commercial competitors and reformers dreaming of a public health insurance regimen remained unresolved. Blue plans grew steadily and commercial plans nipped at their heels but, Roosevelt's silence notwithstanding, providers read the introduction of the Wagner-MurrayDingell bill in Congress in $1943^{1}$ as a worrisome sign that NHI might really happen. The entry of the United States into the Second World War changed the political and economic landscapes, however. The Stabilization Act of 1942, which exempted fringe benefits from federal wartime control on increases in wages, and an administrative tax court ruling in 1943 that employers' contributions to the purchase of workers' health insurance were excluded from the taxable income of employees, gave a boost to enrolment in voluntary (and, increasingly, commercial) plans (Thomasson, 2003). ${ }^{2}$

In Britain, wartime decimation of the health system and the egalitarian agenda of the Beveridge Commission paved the way for the post-war National Health Service. In the United States, the war years saw the flowering of private health coverage, and their end brought the Cold War and a resurgent conservatism resolved to fight fiercely

${ }^{1}$ Named for its sponsors, Democratic Senators Robert Wagner of New York and James Murray of Montana and Democratic Representative John Dingell of Michigan, the bill aimed to add health coverage to the social security system through employer and worker contributions to a trust fund that would pay for physician services and up to 30 days of hospital care.

${ }^{2}$ Pace conservatives who fixate on these rulings as the evil genius behind the spread of health insurance, they were a boost, not a lease on life. Employerbased health insurance had been growing steadily before the rulings were promulgated (Hacker, 2002; Glied, 2005). 
against communism, socialism and, of course, socialized medicine, as lately incarnated in the National Health Service. When President Harry Truman renewed the fight for NHI in the late 1940s he was opposed not only by the two usual suspects - organized medicine and the business community (congenitally allergic to so-called big government interventions except those of benefit to themselves, and increasingly integral to private health coverage) - but also by a new one, a formidable lobby of Blue and commercial plans that argued, not implausibly, that the United States was proudly in process of meeting the citizenry's coverage needs with voluntary and private arrangements that honoured American mores and values. Meanwhile, proposals for a universal public plan, which had never enjoyed serious organizational support outside segments of the labour movement, lost much of the little that it had as unions, ever protective of their private collective bargaining prerogatives, increasingly joined the private club by creating their own Taft-Hartley health insurance plans ${ }^{3}$ (Gottschalk, 2000). As the ranks of Americans with health coverage skyrocketed from 10\% in 1940 to $76 \%$ in 1957 (Mayes, 2005: p.48), NHI was ceasing to be "culturally conceivable" (Dobbin, 1994: p.228).

\section{Medicare and Medicaid}

During the Eisenhower years (1952-1960) proponents of universal coverage shifted ground from insistence that NHI was the one right way, to reiteration that the voluntary/private health insurance system could not feasibly cover sizeable swaths of the population, especially older people, who, having retired from the workforce, stood outside the reach of employer-based insurance, and the unemployed. Various small federal programmes offered grants to induce the states to pay some of the medical bills of lower-income older people, but results were disappointing. Both the benefits and the costs of medical care for older people were growing steadily and, in a surge of mini-solidarity,

${ }^{3}$ Named after Republican Senator Robert Taft of Ohio and Republican Representative Fred A. Hartley Jr of New Jersey, these created, in 1947 legislation, multi-employer health and welfare trusts, jointly managed by labour and management representatives, that held their assets in a trust fund, bargained collectively with each participating employer and enabled workers to keep their health coverage if they changed jobs among employers in the fund. 
public opinion duly noted that neither the aged nor their expectant heirs deserved to see their savings and assets depleted by medical bills. Organized medicine had concerns about the savings and assets of its own members but - although new paying customers would have been nice, if these came at the price of greater federal regulation of fees and practices, charity care was the lesser evil - its aggressive opposition stalemated legislation until the national elections of 1964 gave liberal Democratic President Lyndon B. Johnson a landside victory, accompanied by the arrival of a large new contingent of liberal Democrats in both houses of Congress. The next year the famous three-layer cake - Medicare Part A for hospital care of older people, Medicare Part B for their physicians' services and Medicaid for some of the poor (including indigent older people) - became law. As Hacker (2002) notes, this enormous public breakthrough was not a repudiation of the voluntary/private system but rather (in effect) an endorsement of its basic premise: the non-public status quo worked well for most of the population but inevitably left gaps in coverage, which it was the government's role to patch and fill.

The implementation of Medicare and Medicaid in 1966 set the mould that endures today. Data from 2015 show that $20 \%$ and $14 \%$ of the US population are covered by Medicaid and Medicare, respectively (Henry J. Kaiser Family Foundation, 2015).

For 3 years after enactment of the new federal programmes, liberals surmised that this long-sought breaching of the barricades against a major federal role in funding coverage and care presaged incremental slicing of the "salami" until universal coverage was achieved. By 1968, these hopes were gone. The nation was in political turmoil over conflicts domestic (race tensions, urban riots) and foreign (the Vietnam War), the costs of Medicare and Medicaid far exceeded projections, and the election of Richard Nixon, a Republican, to the White House signalled a rightward shift that pushed NHI off the public agenda. Attention turned to two questions: how to contain health care costs, which were rising fast enough to prompt talk of a cost crisis (Hackey, 2012), and how to design health coverage for those outside the employer and public systems. The two questions connected less symbiotically than parasitically: efforts to solve one drained energy from attempts to address the other, leaving another round of policy stalemate and frustration that proved to be long-lived. 


\section{The managed care era: rescue and miscue}

Costs dominated the federal agenda partly because medical progress is impressive but not cheap (technology and medical innovation are a clinical blessing and fiscal curse to public and private purchasers alike) and partly because a single federal purchaser/payer (plus the 51 single Medicaid purchasers/payers in the states and Washington, DC) were now directly and heavily implicated in the problem. Policy-makers spent countless hours worrying about health care policy and sought advice from all the best minds whose views fitted their ideological predilections. The Nixonites soon learned that the cost problem had two fundamental sources - moral hazard and provider dominance - both of which were aggravated by (indeed institutionalized in) the synthesis of third party insurance and fee-for-service medical practice that characterized the US system. The correction, the policy-makers were pleased to hear, need not disrupt the voluntarism and privatism of that system - rather it mainly served to perfect and expand it by introducing new measures of consumer choice, correct incentives and competition - in a word market forces. Health Maintenance Organizations (HMOs; of which prepaid group practice plans such as Kaiser Permanente were an example but by no means a blueprint) would let consumers choose plans that ran efficiently because they combined the financing and delivery of care within an integrated organizational framework and subjected providers to fiscal and managerial discipline. When obliged to compete with HMOs that offered good access and quality at lower premiums, lax Blue and commercial plans would have to shape up or cede market share. A few federal grant and loan dollars would give entrepreneurs the incentives to build HMOs whose correct incentives would in turn beam into the whole system further incentives to change its wanton ways. Gatekeeping and other tools to channel access would smite moral hazard while organizational controls would dethrone sovereign providers (Brown, 1983).

The Nixon administration also proposed a Comprehensive Health Insurance Plan, thoroughly grounded in the private system, which would have required most employers to cover their workers. Though a far cry from the NHI templates that were still alive and well (at least rhetorically) in the early 1970s, the plan was not absurd prima facie: the great majority of uninsured Americans were (then as now) workers (or dependants), mainly in lower-paid jobs in small firms. For 
better or worse, negotiations among the administration and the two key Democratic legislators (Representative Wilbur Mills and Senator Edward Kennedy) collapsed in 1974, even as the newly minted measure to promote HMOs began to be implemented (Blumenthal \& Morone, 2009: pp.242-6).

The story of HMOs (soon to be known as managed care organizations) has had a fairly clear beginning, middle and end. Because this new organizational form challenged the standard practices of all those involved in making it work - consumers, employers, insurers, providers and government itself - HMOs diffused and gained enrolment slowly between 1975 and 1985. By the mid-1980s, however, three factors - unabated increases in health costs, lack of consensus on what system-wide regulatory strategies (if any) to adopt and (probably most important) myriad organizational innovations that made HMOs less rigorous (and also less effective) controllers of care and cost - prompted a fresh and increasingly favourable look at these plans by all the players noted above. By 1990, managed care plans had conquered the private sector and replaced old-fashioned insurance as the mainstream model. (The public sector's own ventures in managed care, meanwhile, were a study in contrast: in Medicare, which deferred to the rights of beneficiaries on the free choice of provider, penetration hovered around a meagre $10 \%$. In Medicaid, which permitted the states to put beneficiaries into managed care, enrolment exceeded $50 \%$.) The dominant institutional form managed care assumed was the preferred-provider organization - in which insurers contracted with providers who essentially added their names to a list of those willing to accept a measure of utilization review and some withholding of revenues to keep the plan reliably afloat but otherwise practised much as before - was a far cry from the integrated prepaid group practices such as Kaiser Permanente that launched visions of health maintenance organizations in 1970.

During the 1990s it gradually dawned on all but the most fervid aficionados of managed care both that the dilution of organizational controls so crucial to the diffusion of managed care plans had severely weakened their power to contain costs and that a backlash by consumers and providers was reducing the number of cost-containing arrows that remained in the controllers' quivers. In the latter half of the 1990s, the growth of health costs slowed impressively, though how much credit goes to managed care, to insurance cycles and to lingering caution among insurers and providers, traumatized by the prospect of health reform 
(which in the early 1990s had been widely viewed as imminent before it collapsed in 1994 and could presumably return from the dead), into holding the line on prices is impossible to say. In any case, after 2000, managed care no longer looked like much of an answer to the cost problem and weary policy-makers wondered what to do for an encore.

\section{Why not manage competition?}

To some on the left (then three decades out of office and public favour) the managed care episode proved that the nation's employer-based private health insurance system was hopeless, and that wisdom lay in emulating the NHI systems of other, wiser western nations with all deliberate speed. One strategic variant on market forces however, which would impose public management on otherwise unmanaged competition among managed care plans, both enjoyed high-level consideration in Washington and ran parallel to reform projects unfolding in Switzerland, the Netherlands, Israel and the internal market in the United Kingdom. The theory of managed competition saw managed care as a step in the right direction but also a potential source of market failure. Left alone, HMOs might seek profits and market share by misrepresenting the nature of their providers and products, segmenting markets, underserving enrollees and selecting preferred risks. Incentives could not be truly correct without a framework of pro-competitive regulations crafted and enforced by government (Enthoven, 1980). In his health reform proposals of 1993/1994, President Bill Clinton sought to harmonize the public and private sectors, an employer mandate and managed care into a seamless legislative package designed to satisfy both the left and right of the political spectrum and key interest groups. Alas, a public hand visible and vigorous enough to rationalize the unwieldy US health system attracted boundless derision and negligible political support (see Johnson \& Broder, 1996; Glied, 1997; Hacker, 1997; Skopol 1997).

The demise of the Clinton plan in 1994 tossed the system back onto unmanaged competition among managed care plans, and a few years later the collapse of confidence in managed care left policy-makers facing their old nemeses: moral hazard and provider dominance. The administration of George W. Bush got back to basics: costs ran high because consumers paid too little for their health care, and health savings accounts (known euphemistically as consumer-driven health plans and accurately as high-deductible health plans) would give consumers the 
latest model of correct incentives to avoid using too much care and to shop for cheaper providers. Critics panned this strategy as a reductio ad absurdum of 30 years of policy regression, social unlearning and unintelligent design.

Though the trend went largely unheralded, during the administrations of Clinton and Bush, public insurance plans increasingly became dominated by private insurers. In Medicare, the Medicare Advantage programme gave beneficiaries extra benefits and reduced out-of-pocket payments if they chose private managed care plans rather than fee-forservice Medicare. State governments, seeking stability in health care prices, increasingly contracted with private insurers for their Medicaid programmes. Today, nearly a third of Medicare enrollees are enrolled in private health plans (Henry J. Kaiser Family Foundation, 2016c). Similarly, the vast majority of Medicaid enrollees are enrolled in private health plans.

\section{The Affordable Care Act}

During the national elections of 2008, health care scored high on lists of the public's concerns and all the leading presidential contenders issued reform proposals of greater or lesser detail. As usual, the employerbased system of coverage, now intimately intertwined with the private health insurance industry, came under fire. Single-payer advocates, citing Canada as a model, would have done away with work-based coverage and private health insurance in one fell swoop. Some reformers argued for retaining employer coverage but mandating it for all but the smallest firms, while others sought to make the system less employercentric but more private by encouraging health savings accounts; by mandating that each individual citizen acquire health insurance through employment or otherwise, with the assistance of public subsidies for those who could not afford to do so with their own (or their employers') funds; or by expanding tax credits or deductions to spur the voluntary purchase of private coverage.

The ACA of 2010 altered the roles and prerogatives of private health insurance in ways that are less than fundamental but more than merely marginal. In elections in November 2008, buoyed by multiplying Republican misadventures and misfortunes (capped in September 2008 by a severe economic downturn) the Democrats won the White House and achieved sizable majorities in both congressional chambers. 
President Obama and congressional leaders wanted to enact health reform legislation, believed that they had political support sufficient to bring it off, and quickly set about crafting measures that aimed to reconfigure the private/public mix with due respect for political reality. Despite intense controversy and intractable Republican opposition, the Democrats' stratagems worked: party unity held, congressional draftmanship was constructive, the legislative package (closely modelled on reforms enacted in Massachusetts in 2006) proved serviceable, and cost containment conundrums did not derail consensus (Beaussier, 2012). Not least important, the traditional forces of opposition splintered. Business groups, notably the Chamber of Commerce, resisted the reform plan, but organized medicine lent support in exchange for the promise of political leaders to fix a Medicare formula that annually threatened reductions in their payments (Laugesen, 2011), and leaders of the private health insurance industry agreed that the protections against adverse selection that accompanied a federal mandate that almost all citizens buy health coverage, made newly tolerable the restrictions on their rating and enrolment practices that reformers were bent on imposing (Brown, 2011).

The law that emerged in March 2010 changed the rules of the game for private insurance in several ways. By the end of 2010, new protections allowed consumers to compare health insurance coverage options, prohibited insurance companies from denying coverage of children based on pre-existing conditions, prohibited insurance companies from rescinding coverage, and eliminated lifetime limits on insurance coverage. In 2014, consumer protection laws were further expanded under the ACA. Insurance companies were prohibited from discriminating on the basis of pre-existing conditions or gender, and annual limits on insurance coverage were eliminated (US Department of Health and Human Services, 2015). Insurers are now required to take all comers, and, within a region and market segment (individual versus small group) can charge higher rates only to a limited extent based on age and tobacco use.

The law created a national health insurance exchange - marketplace - for the highly regulated sale of private insurance, but also allowed states to set up their own exchange for all or some of the activities involved in such sales. By 2016, 12 states had their own exchange, 28 deferred to the federal version, and the rest had exchanges that shared some functions with the federal exchange. Each exchange operates 
a system of risk adjustment, transferring money from insurers who cover healthier people to those who cover sicker people. Low- and moderate-income consumers who purchase through these marketplaces are eligible for tax credits. The existing Medicaid programme has been expanded; in most states, this programme uses private insurance plans. Since the beginning of 2014, the law has mandated that all but the poorest citizens buy health insurance or face a financial penalty, although this penalty has since been eliminated. By 2015, companies with 100 or more full-time workers were required to insure a minimum of $70 \%$ of their full-time employees. Companies with 100 or more full-time employees were required to have $95 \%$ of full-time staff insured, and small businesses with 50 or more full-time employees were required to start insuring full-time workers by 2016 . Depending on average annual wages, employers with 10 or fewer full-time employees qualify for employer tax credits through the ACA's Small Business Health Options Program.

The law also regulates, to some extent, the content of insurance and the nature of the industry. Health insurers must devote at least $80 \%$ ( $85 \%$ in the case of large group insurers) of their revenues to clinical care; are no longer allowed to impose co-payments and deductibles on preventive measures such as immunizations, check-ups and screenings for a range of conditions; must market policies on a guaranteed issue and renewal basis; must limit waiting periods for the onset of coverage to no more than 90 days; and must justify unreasonable premium increases to public authorities.

These innovations in the ACA leave the character of the US system closer to, but still well distant from, other western models of affordable universal coverage (Rodwin, 2011). The sustainability (indeed the survival) of these reforms is far from assured. The court of public opinion has been slow to embrace the reform. In 2016, the Kaiser Health Tracking Poll found that Americans' opinion of the ACA was split down the middle $-45 \%$ favourable and $45 \%$ unfavourable. Most Democrats $(76 \%)$ favoured the ACA while a majority of Republicans $(83 \%)$ did not. Among Independents, $52 \%$ were unfavourable to the health care law (Kirzinger, Sugarman \& Brodie, 2016)

Meanwhile, electoral politics portend further uncertainties since the Republicans captured control of the White House and both chambers of Congress in the elections of November 2016. Throughout the campaign, 
President Donald Trump repeatedly declared that the Affordable Care Act would be repealed - and replaced with something better - once he took office. Additionally, during his presidential campaign, Trump also proposed a series of measures that would allow people to obtain affordable health insurance policies outside exchanges established by the ACA (Jost, 2016). These measures include helping people save money to pay for tax-free health saving accounts, allowing individuals to deduct premium costs on their personal income tax returns, and permitting insurance companies to sell policies across state lines, to increase competition. One of the biggest hurdles to repealing the ACA is that approximately 20 million people have gained health insurance under it. Depending on the alternatives put in place if the law were repealed, some 25-32 million more Americans would likely become uninsured (Kodjak, 2016; Congressional Budget Office, 2017).

Since the implementation of the ACA, about 12.7 million people have found coverage in the marketplaces, and approximately 20 million people overall have been insured by the Marketplaces, Medicaid expansion, young adults remaining on their parents' plan, and other provisions of the law such as requiring plans to cover people with preexisting conditions (US Department of Health and Human Services, 2016). The Centers of Disease Control and Census data show that the uninsurance rate decreased from $15.7 \%$ to $8.6 \%$ since the ACA began.

For some groups within the US population the increase in coverage has been especially striking. For the 18-64 demographic, the uninsured rate fell to $11.9 \%$ from $22.3 \%$ when the ACA was signed in 2010 (ObamaCare Facts, 2016b). The law has also had a significant impact on the immigrant population. States that decided to expand Medicaid after the beginning of 2014 now offer the programme to US citizens and lawfully present immigrants whose incomes are at or below $138 \%$ of the federal poverty level and who have been residing in the United States for more than 5 years (National Alliance of State and Territorial AIDS Directors, 2014). By contrast, undocumented immigrants have not become eligible for new coverage under the ACA (ObamaCare Facts, 2016a).

\section{Private health insurance Pre-ACA}

Pre-ACA, private health insurance in the United States occupied three distinct markets. First, there were voluntary or compulsory options in 
public insurance plans. For example, in 2010, 24\% of Medicare beneficiaries chose to enrol in private Medicare advantage managed care plans. Two thirds of these enrollees were in HMOs, the rest were in preferred-provider organizations or hybrid plans. (The other $75 \%$ or so of beneficiaries remained in traditional Medicare, the nation's last remaining island of freedom of choice and fee-for-service payment.) And in $2010,71 \%$ of Medicaid beneficiaries were enrolled (most of them mandatorily) in mainly private managed care plans before the ACA (Centers for Medicare and Medicaid Services, 2016).

Second, private coverage supplements public insurance in Medicare. Roughly two thirds of the Medicare population had private coverage over and above the programme's benefits for physician and hospital care. The prescription drug benefits added to Medicare in 2003, moreover, were allocated entirely via private plans. About $39 \%$ of beneficiaries received this coverage in stand-alone drug plans, another $23 \%$ were in employer-sponsored plans, and 18\% more benefited from drug coverage through Medicare Advantage plans that also supplied the programme's physician and hospital benefits. Employers also opted to give retirees health coverage of greater or lesser scope in private plans (Henry J. Kaiser Family Foundation, 2016d).

Third, most of the US population that was neither in Medicare, Medicaid or military health systems nor uninsured received coverage from a private market segment, of which the most important are group health insurance sponsored by employers (about one third of the population under 65); coverage supplied by means of self-insured employer plans (the employer assumes financial risk for workers and contracts with a private health insurer or third party administrator for so-called administrative services only); individual, nongroup coverage (about $7 \%$ of the under- 65 population); and a few multi-employer plans and assorted hybrids (Henry J. Kaiser Family Foundation, 2015).

The private health insurance firms in question show a pronounced trend toward concentration. Before 1975, the industry split among multiple commercial insurers and Blue Cross/Blue Shield (which did not allow for-profit plans within its ranks until 1994), most of which had small market shares. In 2015, there were 5926 insurance companies offering health insurance in the United States and territories. Of these, 2544 were property and casualty companies (which primarily sell auto, home, and commercial coverage), 872 sold life/annuities policies, and 859 issued health insurance (Insurance Information Institute, 2015). By contrast, 
the group market is highly concentrated. In 2008 the five largest of the 30 top health insurance companies (United Health Group, WellPoint, Aetna, Health Care Service Corporation and CIGNA) accounted for about $55 \%$ of total medical enrolment (Austin \& Hungerford, 2009: p.10, table 1).

There has been an increase in industry concentration over the past decade. Between 2006 and 2014, the market shares of the four largest insurers (Blue Cross Blue Shield, Anthem, United and Aetna) have seen a nine-percentage-point increase $(74 \%$ to $83 \%)$ in the four-firm concentration ratio for the sale of private insurance. Between 2011 and 2015, insurer concentration also increased in the Medicare market, with a $13 \%$ increase in the combined market shares of the four leading Medicare Advantage insurers (Dafny, 2015).

In 2010, the annual report of the American Medical Association detailed market share data for the top two insurers, showing that the average degree of concentration in insurance markets is higher within metropolitan statistical areas than in the nation as a whole. In 313 metropolitan areas examined, $99 \%$ of $\mathrm{HMO}$ and preferred-provider organization markets were highly concentrated (up from $94 \%$ a year earlier). The percentage of these markets in which one insurer had at least $50 \%$ of the market had risen from $40 \%$ in 2009 and 2010 to $50 \%$ in 2010. In 24 of 43 states studied, the two largest insurers held a combined market share of $70 \%$ (up from 18 states of 42 studied the year before) (Emmons, Guardado \& Kane, 2010). Although some nonprofit and mutual insurers remain, for-profit firms have been the most common form of ownership in the industry since the 1990s (Viswanathan \& Cummins, 2003). Adding for-profit Blue Cross Blue Shield plans raises the market share of the Blues to $44 \%$ from the $31 \%$ covered by their non-profit plans (Robinson, 2004). Providing medical coverage to about 104 million members, Blues plans and affiliates commanded more than $60 \%$ of the market share for health insurance in nine states in 2015 (Mark Farrah Associates, 2015).

Public regulation of private health insurance takes myriad arcane forms that are opaque to many policy-holders and policy-makers alike. The Medicare and Medicaid programmes regulate private health insurance policies that enrol their beneficiaries. Insurance that supplements Medicare is regulated partly by the federal government (which allows only certain standardized policies to be sold) and by the states (excepting Medicare Part D plans, state regulation of which is partly pre-empted 
by the federal government). Outside public programmes, before the ACA, states had primary responsibility for regulating private insurance, although the Health Insurance Accountability and Portability Act of 1996, a wide-ranging law that aims (among other things) to improve the portability of coverage for workers who lose or change jobs, gave the federal government new regulatory powers (for example, limiting the use of pre-existing conditions by health plans as a basis for restricting benefits). Federal rules on the enrolment and pricing practices of private insurers were expanded by the ACA in 2010 and largely overrode these state rules.

States seek to assure the solvency of insurers (lest carriers be unable to pay as promised) and have set special rules for small groups (those with fifty or fewer workers). Well before ACA, all but three states required that policies be guaranteed as renewable ${ }^{4}$ at the average rates charged to other members of the rating class (Patel \& Pauly, 2002). A few states mandated that plans also practise guaranteed issue (insurers must take all comers, without underwriting, though perhaps subject to pre-existing condition clauses) and community rating in the small group or individual markets (Pauly \& Herring, 2007). About 35 operated highrisk pools that made it somewhat (though seldom markedly) easier for individuals at high risk to buy coverage (Chollet, 2002; http://naschip .org/portal/) and all states regulated the content of health insurance sold within their borders. They might specify the providers whose services must be covered (for example, chiropractors); the benefits that must be provided (for example, mental health care) and the populations that must be included in insurance offerings (for example, children). Insurers and small business lobbies have long complained that these accumulating mandates are a reason - some say the main reason - why the cost of coverage is high and have urged state governments to prune them to a bare minimum.

A federal law - the Employee Retirement Income Security Act of 1974 (ERISA), which aimed to stop corruption in pension plans but also acquired a regulatory role over health plans in their capacity as employee welfare benefit plans - exempts employer-funded (self-insured) plans

${ }^{4}$ Insurers must reissue guaranteed renewal policies to individual subscribers and do so without regard to changes in the health of individuals, although insurers may limit these policies to fixed terms and may - and usually do - change premiums for the entire group covered by that specific policy. 
from state regulation, even if they buy commercial reinsurance (as most do) above a plausible stop-loss level. After ERISA passed, the fraction of firms opting to self-insure rose from about $25 \%$ (pre-1980) to $60 \%$ in the mid-1990s, and then settled at about $50 \% .^{5}$ In $2009,82.1 \%$ of firms with 500 or more workers offered at least one self-insured plan, but only $25.7 \%$ of firms with $100-499$ workers and $13.5 \%$ of those with fewer than 100 workers did so (US Department of Health and Human Services, 2011: p.3). Beyond reporting requirements and delineation of the fiduciary duties of plan administrators, ERISA rules were, until 2010, remarkably few. In principle, an ERISA plan could choose not to cover a disease (HIV, for instance), decline to insure children, require a 1-year waiting period before coverage commences, contract only with Christian Science doctors or require employees to pay the whole premium. Nor are such plans subject to managed care malpractice laws.

Other important pieces of the pre-ACA regulatory picture include provisions of the federal Consolidated Omnibus Budget Reconciliation Act of 1985, which required that all plans, self-insured included, allow workers in firms of 20 or more who leave a job (whatever the reason) to continue their health coverage for up to 18 months by paying the full premium themselves. The 1996 Health Insurance Accountability and Portability Act mandated that all insurers (including self-insured plans) enrol anyone who had been previously insured without regard to pre-existing conditions - albeit without restriction on the size of the premiums plans choose to set for this coverage. In 1996 the federal government also gave self-insured plans a taste of the detailed mandating that is so controversial at the state level by obliging plans that offer maternity benefits to cover a 48-hour maternity stay in a hospital. The same year also brought mental health parity legislation: plans that offer mental health benefits cannot impose more stringent annual dollar limits on those services than on general health care; this restriction was further expanded in 2008. In 1998 national legislation required that all plans cover reconstructive surgery for mastectomy patients.

The ACA partially ended laissez faire for self-insured plans. Where and how these plans fit within the catalogue of group health plans caused

${ }^{5}$ The decline may reflect the complexities of self-insurance in managed care plans, which merge the risks and costs of corporate customers, whereas under a straightforward fee-for-service indemnity arrangement, services are used by the firm's employees, claims come in and money goes out, perhaps through an administrative services entity. 
the law's authors no small vexation, and the resolution predictably embodied complex compromises, several of which continue to require regulatory or judicial explanation. On the one hand, ACA imposes "a significant number of requirements regarding both the eligibility for plan membership and the scope of the benefits that self-insured plans must provide." So-called musts include timely notification of "material" changes in employee coverage, coverage without cost sharing of a range of preventive services, payment of fees to help support the PatientCentred Outcomes Research Fund, and direct access of women to a gynaecologist or obstetrician without referral by a primary care physician. Among the cannots are prohibitions against: imposition of annual limits on essential health benefits after 2014, rescission of employee coverage except in cases of fraud or misrepresentation, and discrimination based on health status, including pre-existing conditions. All the same, self-insured plans are "not nearly as comprehensively regulated... as insured plans are." For example, they remain exempt from offering certain benefits, from limitations on annual limits on deductibles, and from requirements that guarantee the issue and renewal of coverage (Temchine, 2010: p.2). In practice, the benefits, premiums and other features of self-insured firms look very similar to, and indeed perhaps somewhat more generous than, those found in insured firms. This is not surprising: self-insured firms tend to be larger and to have higher-paid workers than their non-self-insured counterparts (Acs et al., 1996).

\section{Group markets, large and small}

The many inequities and complexities of private, employer-based coverage in the United States have moved critics to contend that these arrangements are an anachronism the expiry date of which should have long since passed, and that any reform worthy of the name must radically reconfigure that system if not junk it outright. The employer role is more subtle than these categorical indictments acknowledge, however. All health care financing systems are employer-based in at least one of two senses. First, corporate and other taxes on business firms enrich the base of general revenues that fund health care even in single-payer nations without insurers (private or other) for basic coverage. Second, countries with social insurance systems are overtly employer-based. Payroll taxes on employers and workers are the mainstay of the trust funds on which sickness funds draw to pay providers. These taxes have 
at least two salient limits, however: they are vulnerable to the declining ratio of worker-contributors to beneficiaries over time, and they leave untapped sources of wealth (capital gains, real estate and so on) that have gained prominence since Bismarck unveiled social insurance for health care in 1883. As birth rates decline while the ranks of retirees grow, these extractive limits are much on the minds of policy-makers in (for example) France, Germany and US Medicare, who have responded by infusing larger sums of general revenue into their health systems, thus adulterating Bismarck with Beveridge.

Before the ACA was passed, employers had the freedom to offer health insurance voluntarily for recruitment, retention and improvement of the health and productivity of staff. They were also free to determine the contents and financial terms of coverage - or to decline to cover workers (and dependants) at all. Provisions of the ACA have had a significant impact on employer-based coverage. Its Employer Mandate (a component of the Employer Shared Responsibility Provision), requires all employers with 50 or more full-time equivalent employees to offer health insurance for a minimum of $95 \%$ of their full-time employees (and offer it to their dependants), or face penalties (for example, US\$2000 per full-time employee after the first 30 employees if no workers are covered). Employees, however, do not have to accept the employeroffered coverage (ObamaCare Facts, 2015).

Employer-based though it be, the US health system accepts government mandates on employers uneasily if at all. Before the ACA, federal government declined to enact a national employer mandate (plans to do so in the Clinton reform infuriated small business lobbies and won little support from big businesses, one of many cautionary tales on the minds of the Democrats who designed the ACA in 2009/2010). Meanwhile the national ERISA statute prohibits the states from passing mandates of their own. (Hawaii, for reasons of no great importance here, is the sole exception.) No wonder that American reformers (not to mention foreign observers) often contend that employer-based private health coverage should be thrown out of the next open window of opportunity.

The case against the US version of employer-based coverage is far from airtight however. Between 2001 and 2011 97-99\% of large firms (those with 200 or more workers) offered health benefits and, complaints about high cost notwithstanding, these larger firms show little inclination to stop doing so. The much-noted decline in the share 
of business offering health benefits from $68 \%$ in 2001 to $56 \%$ in 2016 occurred almost entirely among small and mid-sized firms (Henry J. Kaiser Family Foundation, 2016a). The large-group sector of employer coverage remains reasonably stable because health benefits help firms to attract and retain the workers they want, because some executives believe that offering coverage is the right thing for paragons of private enterprise to do and because they can shift some of the rising costs of health insurance to their workers by requiring them to contribute more to premiums, by raising wages more slowly, or by increasing cost sharing in health plans. The average worker contribution to the total cost of family coverage stayed fairly steady - around $28 \%$ - between 2001 and 2016. Cost sharing, however, has increased 2.5-fold since 2006. On average, workers with family coverage contribute US $\$ 5277$ annually toward their health insurance premiums, whereas workers with single coverage spend approximately US\$1129 annually (Henry J. Kaiser Family Foundation, 2016a). Employers that represent big books of business wield clout as they bargain for better deals with competing insurers, enjoy some flexibility in seeking a larger, better or different mix of benefits or providers, and have pursued their purchasing largely without the benefit (or handicap) of public regulation. Rising costs have eroded coverage among larger groups, but not very much, and certainly not enough to validate alarms about the collapse of employer-based coverage (Glied, 2005).

The small group and individual insurance market is another world, however, one in which the employer-based system falters badly. In $200158 \%$ of firms with fewer than 10 workers offered coverage, but by 2005 that proportion had fallen to $47 \%$, and still had not recovered $(46 \%)$ in 2016 (Henry J. Kaiser Family Foundation, 2016a). Workers whose "employment situation does not readily lend itself to employment-based coverage", for example, "new economy" workers with contingent employment contracts, multiple jobs and part-year employment; people who change jobs often; and those in firms of 25 or fewer workers - account for "just under half of the active US labour force" (Glied, 2005: p.45).

Self-employed individuals and small firms suffer from limited bargaining leverage, few economies of scale for insurance brokers and agents, relatively little money to spend on coverage, unappealing risk pools and (at least in insurance lore) workers who are in poorer health and more inclined to use care than those in larger groups. As noted above, 
about three quarters of the uninsured were in the workforce, usually though not always in small firms, before the ACA. Unsurprisingly, the uninsured tended to be poorer; and, workers who are younger, non-white, foreign-born and employed part-time disproportionately lacked coverage (Clemans-Cope \& Garrett, 2006). Before the Employer Mandate, the percentage of workers with employer-sponsored coverage descended from $81.3 \%$ of those who earned above $300 \%$ of the federal poverty level, to $41.4 \%$ of those who made $150-199 \%$ of that level, to a meagre $12.6 \%$ for those who were in the $0-99 \%$ category (Fronstin, 2010: p.19, fig. 18).

For years, philanthropic innovators, most notably the Robert Wood Johnson Foundation, sought to fill this market niche by funding grantees to develop deeply discounted insurance products that small firms would agree to offer and their workers to take-up. These programmes repeatedly came up short: very few firms and workers have discretionary cash they are prepared to spend even for lower-cost health insurance, nor do they clamour to trade off relatively low worker wages (or increases in them) for health coverage that these predominantly young employees hope not to use anyway (McLaughlin, 1993; Brown \& Stevens, 2006). Moreover, given the high perceived risks and costs insurers faced by cultivating these markets, such affordable policies as they offered might be sharply restricted by medical underwriting and related stratagems designed to limit insurers' exposure to bad risks. Before the ACA, insurers could require that workers have a medical examination as a precondition of coverage; deny coverage outright or for pre-existing conditions; impose waiting periods for coverage; or tailor group or individual rates to the health status of the group or any of its members. It was of course precisely on this score that private health insurance in the United States departed most drastically from cross-national norms and most readily evoked hoots and jeers. No other nation allows health insurers to compete for profits/revenues on basic coverage by selecting preferred risks and rejecting or heavily penalizing undesirable applicants. In the United States, notes Deborah Stone (1993), solidarity has struggled vainly with actuarial fairness for the soul of health insurance. Rarefied exceptions aside, such scraps of solidarity as open enrolment and community rating failed to gain much ground in an unmanaged competitive market milieu - as early as 1959 , little more than a quarter $(28.2 \%)$ of Blue Cross plans relied solely on community rating in group markets; most combined community and 
experience rating (Thomasson, 2004). The health insurance industry long successfully fought proposals to curtail experience rating and exclusions for pre-existing conditions, but the federal Health Insurance Portability and Accountabiltiy Act of 1996 "sealed some cracks", as noted above. That law, however, did little to constrain their pricing behaviour, yielding a pyrrhic victory - easier access by poor risks to coverage they could not begin to afford (Quadagno, 2005: pp.196-7). In short, the genius of the US health insurance system made it hardest for those who most needed coverage to get it, and thereby triggered demands for the tougher regulations that are now incorporated in ACA.

Even post-ACA, the proposition that equity precludes the expression of invidious distinctions in the enrolment and pricing practices of insurers had not entirely carried the day in the US system. It is not even clear that workers in the large-group sector of the system have stood as immune from exclusionary expedients as conventional wisdom contends. The ever increasing popularity of workplace wellness programmes, which charge higher premiums to workers who engage in unhealthy behaviours, for example, belies solidarity within these pools.

\section{Coverage and culture}

Arguably everyone would be better off if the phrase "national health insurance" were traded for "affordable universal coverage", thus acknowledging that the issue is not individual contracts and prepayments in return for indemnification should illness strike, but rather government's willingly undertaken obligation to pay providers for rendering a very wide range of health services to people within its jurisdiction. The word "insurance", in short, serves mainly to confuse matters. Arguably too, in a sensible system of affordable universal coverage, government would raise from multiple sources the money needed for the health care budget, and define the services to be covered and the terms on which providers will be paid for delivering them - tasks that leave no logically necessary role for insurance and insurers. It is hard to find much social utility in health insurance organizations that have traditionally competed by selecting healthier risks. This private competitive system in the United States has been a major problem per se, working as it has to make coverage least attainable for those who need it most. All the same, social utility is a matter not of logic but of cultural preferences, which vary among and within societies. Bismarckian systems may find 
it comforting to have sickness funds mediating between citizens and a state that stages and bankrolls, but does not entirely run, the show. Some, perhaps many, Americans find in the nation's insurance industry assurance that a half-hearted socialization of risks is not a slippery slope to socialized medicine.

Some citizens might want more services than, or services delivered differently from, what the public plan of basic universal coverage offers - private hospital rooms, dental care, faster access to specialists, for example. So long as basic benefits are adequate and equitable, these preferences can be addressed by a system of complementary or supplemental coverage - perhaps one like the French, in which mutual, non-profit and for-profit insurers compete for subscribers who pay for the extra benefits out of pocket or with contributions by employers or (for the poor) the state.

The United States could adopt such a system only if it were willing radically to revise the roles now played by the business, provider and insurance sectors well beyond the innovations introduced in ACA. Business would participate in funding the system, perhaps by means of payroll taxes, surely through extractions via corporate taxes, but only supplementary coverage would be offered at the discretion and on the terms of employers. Providers (physicians, hospitals and others) would be paid fees (or salaries or capitated sums and so on) set in negotiation with government agencies (or perhaps intermediary agents such as sickness funds). Health insurance might survive institutionally (sickness funds that could compete, if at all, only within rules that proscribed selection of preferred risks), but the US health insurance industry would disappear - except, again, in markets for extra coverage or as carriers for public programmes.

Considerations of profit and power stand high on the list of obstacles to such a transformation, but cultural factors should not be discounted. The American allegiance to actuarial fairness in private health insurance is no mere accident of omission by policy-makers and a public that somehow fail to notice the cruelties this doctrine inflicts. Rather it reflects deep and culturally distinct images of equity and justice. Other western nations recognize health care (hence coverage for it) as some kind of right (metaphysical, natural, human, constitutional, whatever) that it is a duty of the state to secure and assure. Some Americans may high-mindedly call health care a right but when confronted with the corollary $-\mathrm{a}$ right is something the state must realize for all citizens 
(and legal residents) - they tend to demur. In American-ese health care is less a right than a very special "good" - a good of such surpassing importance that society should do everything possible (including the crafting of sizeable public subsidies) to spread it around privately, at which point - and only at this point - one might (perhaps) extend public coverage to those - and only to those - who deserve it but cannot feasibly acquire it privately.

This world view has still deeper roots of its own. Other western nations tend to honour redistribution and cross-subsidies between haves and have-nots (in this case, the sick and the poor) as the equitable essence of social justice. In the United States, redistribution and cross-subsidies from above to below are eternally problematic and contested - and most certainly so in the health sphere, wherein "good risks deserve good rates" is deemed only fair although (perhaps indeed because) it inverts European notions. This mind-set seems to be an amorphous amalgam of the importation of principles of life-insurance pricing into health coverage, the triumph of experience rating over community rating, the growing legitimacy of invidious distinctions between fat and lean Americans (and more generally, among lifestyles of varying degrees of self-discipline), and a settled scepticism about the wisdom and fairness of sharing with and shoring up the disadvantaged. In this context, a private health insurance industry engaged in risk selection is a virtue not a vice. That roughly $45 \%$ of the population viewed ACA unfavourably 6 years after its passage suggests that a sharp cultural sea-change toward support for affordable universal coverage has yet to transpire (Kirzinger, Sugarman \& Brodie, 2016).

Americans might of course be expected to lament the plight of approximately 28.5 million cohabitants who lack health coverage, and so they do. This uninsured population are mostly $(75 \%)$ US citizens and $21 \%$ are non-citizens (Henry J Kaiser Family Foundation, 2016b). The nation stands little risk of protesting too much, however, because another distinctive American institution - the safety net - ensures that those who lack coverage can still get some care. Conservatives (including eminences such as George W. Bush and Mitt Romney) have long averred that in America anyone who needs medical care can go to the emergency room. The uninsured can indeed get care - so long as the care they need can be supplied in those emergency rooms or by primary care providers in community health centres, public health clinics, free clinics and public hospitals, and does not entail much by way of referrals to specialists, 
long inpatient stays, expensive technological treatments or prescription drugs. Such advanced interventions may - or may not - get an uninsured patient qualified for Medicaid and may - or may not - be provided and then billed to public uncompensated care accounts or written off as bad debt, the incurrers of which may or may not be hounded by bill collectors seeking to recover part of the cost of the care the safety net delivered. Whether such rationing of care tips the scales for or against the interests of uninsured patients, and whether positive interventions come in time to save or improve their health, is an almost entirely implicit matter - that is, at the behest of providers themselves. Whether the public understands that the safety net glass is at best half full is unclear. Be that as it may, the ironic and dependable success of the safety net in draining moral urgency from health reform has been perhaps the most conspicuously efficient feature of the US health system.

Whatever its eventual fate, the ACA episode can be read as the latest, and probably the clearest, source of evidence of the institutionalized ambivalence that governs the US approach to health care coverage. Private health insurance in the United States is nothing if not resilient. Widely attacked in the mid-1990s as public enemy number one, less favoured even than tobacco companies, the industry rebounded and by the end of the decade had, as Quadagno (2005: pp.163,170) notes, "vanquished any public sector alternative". Another decade on, ACA left that industry more tightly regulated but also contemplating 16 million adverse-selection-free customers thanks to the individual mandate plus financial return on those of the millions more who may enter Medicaid-managed care plans run by private insurers. Given the entrenchment of private insurance, its malingering conflation with allAmerican voluntarist virtues, the raw political power of the insurance industry, the strength it might yet again display in alliance with providers and business lobbies in opposing unpalatable reforms, chronic popular suspicion that a government take-over of the system will only make things worse, and the absence of evidence that all (indeed any) of this is changing much, prospects are dim that private health insurance in the United States will soon be reformed into something resembling a European configuration.

On the other hand, the steady growth of gap-filling by the public sector will likely continue to be essential to save the private system from itself, as has happened with Medicare and Medicaid. Well before the ACA, gap-filling was incrementally transforming the public-private mix. 
When the ACA passed, Medicare covered about 44 million Americans, Medicaid around 49 million, and the Children's Health Insurance Program roughly 8 million - together, almost a third of the population. Add the nearly 50 million uninsured, who depended heavily on public institutions and funds for care, and the public share rose to around half the population. Add millions more who receive employer-based health coverage through government jobs at the local, county, state and federal levels and the proverbial tipping point was already a fait accompli. In 2016, dollars told the same tale as the count of covered lives: about $48 \%$ of the money in the system came from government programmes. The figure rose to around $64 \%$ if one factored in so-called tax expenditures (business deductions for employers for the money they spend to buy health coverage for workers and exclusion of the health benefits thus purchased from workers' taxable incomes amount to more than US\$200 billion in federal revenue foregone annually) and funds spent to cover public employees (Himmelstein \& Woolhandler, 2016). The subsidies and Medicaid expansions in the ACA push the system somewhat farther and faster down this well-travelled road. Which, then - public or private - is centre and which periphery?

The familiar cultural and structural advantages that private insurance enjoys in the United States remain largely intact, and beholders are free to read the ACA as a major step toward contriving new public coverage and authority or as a lamentable capitulation to constraints that leave the system little more coherent than before. The trio of propositions that has long governed US health care policy - diffuse health coverage as widely as possible in private markets, bring government in to fill gaps in those markets, and fund local safety nets to serve those who fall through any remaining cracks - shows little sign of succumbing to solidaristic appeals, and it remains to be seen whether public sensibilities, political leaders and judicial solons will accept the progressive and redistributive policy departures encoded in the ACA. Solidarity remains an effete force in American political life. Health reform in the United States, like the private health insurance system itself, is always about the money, but never only about the money.

\section{References}

Acs $G$ et al. (1996). Self-insured employer health plans: prevalence, profile, provisions, and premiums. Health Affairs, 15(2):266-78. 
Anderson OW (1975). Blue Cross since 1929: accountability and the public trust. Cambridge, MA, Ballinger.

Austin DA, Hungerford TL (2009). The Market Structure of the Health Insurance Industry. Washington DC, Congressional Research Service.

Beaussier A-L (2012). The patient protection and affordable care act: the victory of unorthodox lawmaking, Journal of Health Politics, Policy and Law, 37(2012):741-78.

Blumenthal D, Morone JA (2009). The heart of power: health and politics in the Oval Office. Berkeley, CA, University of California Press.

Brown LD (1983). Politics and health care organisation: HMOs as federal policy. Washington DC, Brookings Institution.

Brown LD (1991). Capture and culture: organizational identity in New York Blue Cross, Journal of Health Politics, Policy and Law, 16(1991):651-70.

Brown LD, Stevens B (2006). Charge of the right brigade? Communities, coverage, and care for the uninsured. Health Affairs, 25(3):W150-W161.

Brown LD (2011). The Elements of Surprise: How health reform happened, Journal of Health Politics, Policy and Law, 36(3):419-27.

Chapin CF (2015). Ensuring American's health: the public creation of the corporate health care system. New York, Cambridge University Press.

Chollet D (2002). Perspective: expanding individual health insurance coverage: are high-risk pools the answer? Health Affairs, Web exclusive (23 October):W349-W352.

Centers for Medicare and Medicaid Services (2016). Medicaid Managed Care Enrollment and Program Characteristics, 2014. Baltimore, MD, Centers for Medicare \& Medicaid Services, with assistance from Mathematica Policy Research.

Clemans-Cope L, Garrett B (2006). Changes in employer-sponsored health insurance sponsorship, eligibility, and participation: 2003 to 2005. Washington DC, Commission on Medicaid and the Uninsured.

Congressional Budget Office (2017). How Repealing Portions of the Affordable Care Act Would Affect Health Insurance Coverage and Premiums. Washington, DC: https:/www.cbo.gov/sites/default/files/115thcongress-2017-2018/reports/52371-coverageandpremiums.pdf; accessed on $15 / 12 / 2017$.

Dafny LS (2015). Evaluating the Impact of Health Insurance Industry Consolidation: Learning from Experience. New York City, The Commonwealth Fund.

Dobbin F (1994). Forging industrial policy: the United States, Britain, and France in the railway age. New York, Cambridge University Press.

Emmons DW, Guardado JR, Kane CK (2010). Competition in HealthInsurance: A comprehensive study of U.S. markets, 2010 update. Chicago, American Medical Association. 
Enthoven A (1980). Health plan: the only practical solution to the soaring cost of medical care. Reading, MA, Addison-Wesley.

Fox D (1986). Health politics, health policy: the British and American experience 1911-1965. Princeton, NJ, Princeton University Press.

Fronstin P (2010). Survey of health insurance and characteristics of the uninsured: analysis of the March 2010 current population survey, Issue Brief 347. Washington DC, Employee Benefit Research Institute.

Glied S (1997). Chronic condition: why health reform fails. Cambridge, MA, Harvard University Press.

Glied S (2005). The employer-based health insurance system: mistake or cornerstone? In: Mechanic D et al., eds. Policy challenges in modern health care. New Brunswick, NJ, Rutgers University Press.

Gottschalk M (2000). The shadow welfare state: labor, business, and the politics of health care in the United States. Ithaca, NY, ILR Press.

Hacker J (1997). The road to nowhere: the genesis of President Clinton's plan for health security. Princeton, NJ, Princeton University Press.

Hacker J (2002). The divided welfare state: the battle over public and private social benefits in the United States. Cambridge, Cambridge University Press.

Hackey R (2012). Cries of crisis: rethinking the health care debate. Reno, University of Nevada Press.

Henry J. Kaiser Family Foundation (2015). Health Insurance Coverage of the Total Population: http://kff.org/other/state-indicator/total-population/?cur rentTimeframe $=0 \&$ sortModel $=\% 7 \mathrm{~B} \% 22$ colld $\% 22: \% 22$ Location $\% 22, \%$ 22sort \%22:\%22asc\%22\%7D; accessed on 15/12/2017.

Henry J. Kaiser Family Foundation (2016a). 2016 employer health benefits: an annual survey. San Francisco, CA, Henry J. Kaiser Family Foundation.

Henry J. Kaiser Family Foundation (2016b). Key facts about the uninsured population. San Francisco, CA, Henry J. Kaiser Family Foundation.

Henry J. Kaiser Family Foundation (2016c). Medicare advantage: http://kff .org/medicare/fact-sheet/medicare-advantage/; accessed on 15/12/2017.

Henry J. Kaiser Family Foundation (2016d). The Medicare Part D Prescription Drug Benefit. (2016b). The Henry J. Kaiser Family Foundation: http://kff .org/medicare/fact-sheet/the-medicare-prescription-drug-benefit-fact-sheet/; accessed on 15/12/2017.

Himmelstein DU, Woolhandler S (2016). The current and projected taxpayer shares of U.S. health costs. American Journal of Public Health, 106:449-52. Insurance Information Institute (2015). Insurance Industry at a Glance: http:// www.iii.org/fact-statistic/industry-overview; accessed on 15/12/2017.

Johnson H, Broder DS (1996). The system: the American way of politics at the breaking point. Boston, MA, Little Brown.

Jost T (2016). Day one and beyond: what Trump's election means for the ACA. Health Affairs Blog, November 9, 2016, http://healthaffairs.org/ 
blog/2016/11/09/day-one-and-beyond-what-trumps-election-means-forthe-aca/; accessed on 15/12/2017.

Kingdon J (2003). Agendas, alternatives and public policy. New York, Longman.

Kirzinger A, Sugarman E, Brodie M (2016). Data Note: Americans' Opinions of the Affordable Care Act. San Francisco, CA, The Henry J. Kaiser Family Foundation.

Klein J (2003). For all these rights: business, labor, and the shaping of America's public-private welfare state. Princeton NJ, Princeton University Press.

Kodjak A (2016). Trump can kill Obamacare with or without help from Congress. National Public Radio; retrieved from http://www.npr.org/

Law S (1974). Blue Cross: what went wrong? New Haven, CT, Yale University Press.

Laugesen MJ (2011). Civilized medicine: physicians and health care reform. Journal of Health Politics, Policy and Law, 36(3):507-12.

Mark Farrah Associates (2015). Blue Cross and Blue Shield still leads in many markets: http:/www.markfarrah.com/healthcare-business-strategy/ Blue-Cross-and-Blue-Shield-Still-Leads-in-Many-Markets.aspx; accessed on $15 / 12 / 2017$.

Mayes R (2005). Universal coverage: the elusive quest for national health insurance. Ann Arbor, University of Michigan Press.

McLaughlin C (1993). The dilemma of affordability: health insurance for small business. In: Helms R, ed. American health policy: critical issues for reform. Washington DC, AEI Press.

National Alliance of State and Territorial AIDS Directors (2014). Health Reform Issue Brief: Immigrants and the Affordable Care Act: https://www .nastad.org/sites/default/files/Immigrant-ACA-IB-March-2014.pdf; accessed on $15 / 12 / 2017$.

ObamaCare Facts (2016a). ObamaCare Facts: ObamaCare and immigrants: http://obamacarefacts.com/obamacare-immigrants/; accessed on 15/12/2017.

ObamaCare Facts (2016b). ObamaCare Facts: uninsured rates: http:// obamacarefacts.com/uninsured-rates/; accessed on 15/12/2017.

ObamaCare Facts (2015). The employer mandate / employer penalty delayed until 2015/2016. ObamaCare Facts: http://obamacarefacts.com/obamacareemployer-mandate/; accessed on 15/12/2017.

Patel V, Pauly M (2002). Guaranteed renewability and the problem of risk variation in individual health insurance markets. Health Affairs Web exclusive (28 August): W280-W289.

Pauly M, Herring B (2007). Risk pooling and regulation: policy and reality in today's individual health insurance market. Health Affairs, 26:770-9.

Quadagno J (2005). One nation, uninsured: why the United States has no national health insurance. New York, Oxford University Press. 
Robinson JC (2004). Consolidation and the transformation of competition in health insurance. Health Affairs, 23(6):11-24.

Rodwin MA (2011). Why we need health care reform now. Journal of Health Politics, Policy and Law, 36(3):597-601.

Skopol T (1997). Boomerang: health care reform and the turn against government. New York, W.W. Norton.

Starr P (1982). The social transformation of American medicine. New York, Basic Books.

Stone D (1993). The struggle for the soul of health insurance. Journal of Health Politics, Policy and Law, 18:287-317.

Swenson P (2008). Good distribution, bad delivery, and ugly politics: the traumatic beginnings of Germany's health care system. In: Shapiro I, Donno D, Swenson P, eds. Divide and deal: the politics of distribution in democracies. New York, New York University Press.

Temchine DDE (2010). The impact of the patient protection and affordable care act on self-insured ERISA health and welfare benefit plans: a guide for administrators of self-insured plans. Washington DC, Epstein, Becker and Green, P.C.

Thomasson MA (2003). The importance of group coverage: how tax policy shaped US health insurance. American Economic Review, 93(September):1873-84.

Thomasson MA (2004). Early evidence of an adverse selection death spiral? The case of Blue Cross and Blue Shield. Explorations in Economic History, 41(October):313-28.

U.S. Department of Health and Human Services (2011). Report to the Congress on a study of the large group market: http:// aspe.hhs.gov/health/ reports/2011/LGHP study/; accessed on 15/12/2017.

U.S. Department of Health and Human Services (2015). Key Features of the Affordable Care Act by year: https://www.hhs.gov/healthcare/facts-andfeatures/key-features-of-aca-by-year/index.htmlfeatures-of-aca-by-year/ index.html; accessed on 15/12/2017.

U.S. Department of Health and Human Services (2016). 20 mllion people have gained health insurance coverage because of the Affordable Care Act, new estimates show: https://www.hhs.gov/about/news/2016/03/03/20-millionpeople-have-gained-health-insurance-coverage-because-affordable-careact-new-estimates; accessed on 15/12/2017.

Viswanathan K, Cummins J (2003). Ownership structure changes in the insurance industry: an analysis of demutualization. Journal of Risk and Insurance, 70:401-37. 